\section{AEROBIC AND RESISTANCE EXERCISE IN PATIENTS WITH RESISTANT HYPERTENSION}

\author{
EXERCÍCIO AERÓBICO E RESISTIDO EM PACIENTES COM HIPERTENSÃO ARTERIAL RESISTENTE
}

EJERCICIO AERÓBICO Y RESISTIDO EN PACIENTES CON HIPERTENSIÓN ARTERIAL RESISTENTE

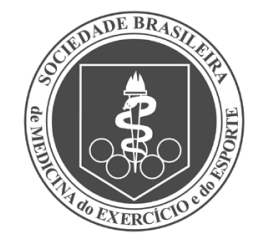

Original Article

ARtigo ORIGINAL Artículo Original
Cristiane Junqueira de Carvalho (Rheumatologist) ${ }^{1,2}$

João Carlos Bouzas Marins (Physical Education Professional) $^{2}$ Carlos Gabriel de Lade (Physical Education Professional) ${ }^{2}$ Pollyana de Rezende Castilho (Physician) $^{1}$

Hamilton Henrique Teixeira Reis (Physical Education Professional) $^{2}$

Paulo Roberto dos Santos Amorim (Physical Education Professional) $)^{2}$ Luciana Moreira Lima (Pharmacist and Biochemist) $^{1}$

1. Universidade Federal de Viçosa, Department of Medicine and Nursing, Viçosa, MG, Brazil. 2. Universidade Federal de Viçosa, Department of Physical Education, Viçosa, MG, Brazil.

\section{Correspondence:}

Cristiane Junqueira de Carvalho. Department of Medicine and Nursing, Universidade Federal de Viçosa. Av. PH Rolfs, s/n, Centro, Viçosa, MG, Brazil. 36570-000. cristcmed@bol.com.br

\begin{abstract}
Introduction: Physical training is recommended by current guidelines as a preventive measure and as a tool to supplement pharmacological therapy in the treatment of hypertension and its pathological manifestations. However, there is considerable uncertainty regarding the best training prescription for blood pressure control in patients with resistant hypertension. Objective: To evaluate the effect, over twelve weeks, of an aerobic and resistance exercise program on blood pressure, anthropometric and biochemical parameters of patients with resistant hypertension. Methods: Eleven patients with resistant hypertension were randomly divided into two groups: resistance training and aerobic training. Blood pressure was recorded by 24-hour outpatient monitoring before and after 12-week training. The Student t-test was used to compare resistance and aerobic exercise groups, while the paired $t$ and Wilcoxon tests were used to analyze pre- and post-exercise data. The level of significance was 0.05 . Results: In the group that underwent aerobic training, mean systolic, diastolic and total blood pressure readings were significantly lower over the 24 hours analyzed, dropping by $14 \mathrm{mmHg}, 7 \mathrm{mmHg}$ and $10 \mathrm{mmHg}$, respectively, and in the waking period. The resistance training group showed no significant change in blood pressure, despite the significant improvement in HDL levels. Conclusion: Twelve weeks of aerobic exercises resulted in significantly lowered blood pressure in individuals with resistant hypertension, while resistance exercises were more effective in increasing HDL. Level of evidence II, Therapeutic study.
\end{abstract}

Keywords: Hypertension; Aerobic exercise; Resistance training.

\section{RESUMO}

Introdução: O treinamento físico é recomendado pelas diretrizes atuais como medida preventiva e como ferramenta adicional à terapia farmacológica no tratamento da hipertensão e de suas manifestações patológicas. No entanto, são muitas as incertezas acerca da melhor prescrição de treinamento para controle da pressão arterial em portadores de hipertensão arterial resistente. Objetivo: Avaliar o efeito, em 12 semanas, de um programa de exercícios aeróbicos e resistidos sobre parâmetros pressóricos, antropométricos e bioquímicos de pacientes com hipertensão arterial resistente. Métodos: Onze pacientes com hipertensão resistente foram divididos em dois grupos aleatoriamente: treinamento resistido e treinamento aeróbico. A pressão arterial foi registrada por monitoramento ambulatorial de 24 horas antes e após o treinamento de 12 semanas. Para a comparação dos grupos com exercício resistido e aeróbico foi utilizado o teste t de Student. Para analisar os dados prée pós-exercício foram utilizados os testes t-pareado e Wilcoxon. O nivel de significância foi de 0,05. Resultados: No grupo que realizou o treinamento aeróbico, os valores médios de pressão sistólica e diastólica e sua média foram significativamente mais baixos no total das 24 horas analisadas, com quedas de $14 \mathrm{mmHg}, 7 \mathrm{mmHg}$ e $10 \mathrm{mmHg}$, respectivamente, e no período de vigília. O grupo de treinamento resistido não apresentou alteração significativa da pressão arterial, apesar da melhora significativa dos níveis de HDL. Conclusão: Doze semanas de exercícios aeróbicos resultaram em redução da pressão arterial de forma significativa em hipertensos resistentes, enquanto que os exercícios resistidos se mostraram mais eficazes no aumento do HDL. Nível de evidência II, Estudos terapêuticos.

Descritores: Hipertensão arterial; Exercício aeróbico; Treinamento de resistência.

\section{RESUMEN}

Introducción: El entrenamiento físico es recomendado por las directrices actuales como medida preventiva y como herramienta adicional a la terapia farmacológica en el tratamiento de la hipertensión y sus manifestaciones patológicas. Sin embargo, son muchas las incertidumbres sobre la mejor prescripción de entrenamiento para el control de la presión arterial en pacientes con hipertensión resistente. Objetivo: Evaluar el efecto, en doce semanas, de un programa de ejercicios aeróbicos y resistidos sobre los parámetros de presión arterial, bioquímicos y antropométricos de los pacientes con hipertensión resistente. Métodos: Once pacientes con hipertensión resistente se dividieron aleatoriamente en dos grupos: entrenamiento resistido y entrenamiento aeróbico. La presión arterial se registró por monitoreo ambulatorio de 24 horas antes y después de 12 semanas de entrenamiento. Para la comparación de los grupos con ejercicio resistidos y ejercicios aeróbicos se utilizó la prueba t de Student. Para analizar los datos antes y después del ejercicio se utilizaron las pruebas t-pareado y de Wilcoxon. El nivel de significación fue de 0,05. Resultados: En el grupo que realizó el entrenamiento aeróbico, los valores promedios de presión sistólica diastólica y su media fueron significativamente más bajos en el total de las 24 horas analizadas, con caídas de $14 \mathrm{~mm} \mathrm{Hg}, 7 \mathrm{mmHg}$ y $10 \mathrm{mmHg}$, 
respectivamente, y en el periodo de vigilia. El grupo de entrenamiento resistido no presentó alteración significativa de la presión arterial, a pesar de la mejora significativa de los niveles de HDL. Conclusión: Doce semanas de ejercicio aeróbico resultaron en reducción de la presión arterial de manera significativa en la hipertensión resistente, mientras que los ejercicios resistidos fueron más eficaces en el aumento del HDL. Nivel de evidencia ll, Estudios terapéuticos.

Descriptores: Hipertensión; Ejercicio aeróbico; Entrenamiento de resistencia.

\section{INTRODUCTION}

Systemic arterial hypertension (SAH) is an important public health problem that affects nearly $32 \%$ of the adult population in Brazil; however, it is also a prominent modifiable risk factor for cardiovascular morbidity and mortality. ${ }^{1}$ Physical activity has many benefits to health, as proven by the known association between sedentarism and a greater risk of diseases, especially cardiovascular diseases. ${ }^{2}$ Thus, physical training has been recommended as a preventive measure and as an additional intervention to pharmacological therapy in the treatment of hypertension and its pathological manifestations. ${ }^{1,2}$

Studies have shown that aerobic training (AT) promotes greater blood pressure $(B P)$ reduction than resistance training $(R T)$ and have recommended AT for BP control. ${ }^{3,4}$ Nevertheless, recent research has demonstrated that the hypotensive effect of resistance exercises can reach similar levels to that of aerobic exercises, depending on the method used. ${ }^{5}$ However, there is a lack of consensus about the best training prescription for BP control in patients with resistant hypertension $(\mathrm{RH}){ }_{1}^{6}$ owing to the diversity of the research protocols used ${ }^{5}$ and the small number of studies that have been performed thus far ${ }^{7-9}$ and also because this population is highly susceptible to adverse cardiovascular events. ${ }^{6}$

$\mathrm{RH}$ is a multifactorial disease that affects between $10 \%$ and $30 \%$ of all hypertensive patients. ${ }^{6}$ It is defined as a kind of hypertension that cannot be controlled with the use of 3 or more antihypertensives, one of which is a diuretic. The definition of $\mathrm{RH}$ also includes hypertension in which BP is controlled with the use of 4 or more drugs. ${ }^{6}$ A recent study has shown that the inadequate pharmacological response to $\mathrm{RH}$ is not always associated with the low efficacy of lifestyle modifications, with aerobic exercise leading to variable BP reductions of $5-15 \mathrm{mmHg}$. Thus, studies with differentiated methodological approaches with respect to the safety and efficacy of physical training for BP control in patients with $\mathrm{RH}$ are necessary.

This study evaluated the effect of a program consisting of aerobic and resistance exercises on the $\mathrm{BP}$, anthropometric parameters, and biochemical parameters of patients with $\mathrm{RH}$.

\section{METHODS}

\section{Sample}

The sample of the present study was selected from the Hiperdia Reference Center of Viçosa, Minas Gerais. Male and female patients with $\mathrm{RH}$, who were aged $>18$ years, and who were not engaged in routine and systematized physical exercises were considered eligible for inclusion. On the other hand, diabetic patients, patients with symptomatic coronary ischemic disease or with electrocardiographic signs of ischemia at rest or during the exercise test, those with BP instability during the exercise test, those with osteoarticular disease precluding training, and those with chronic decompensated diseases were excluded from the study.

Before taking part in the study, all patients underwent clinical and cardiological evaluation with an exercise test with a ramp protocol. Finally, the study sample consisted of 11 patients ( 3 men and 8 women) with a mean age of $60 \pm 8$ years.
The study was approved by the Human Research Ethics Committee of the Federal University of Viçosa, under CAAE no. 28144814.0.0000.5153, opinion 611.816/14, thus complying with the Brazilian Legislation (Resolution 466/12) on human studies. All patients signed the informed consent form.

\section{Study Design}

This was a 12-week longitudinal study in which patients were randomly divided into 2 groups: 5 patients in the RT group and 6 patients in the AT group. Before the beginning of the training and at the end of the 12-week period, all patients underwent anthropometric evaluation, biochemical examinations, and 24-h BP recording using an ambulatory $\mathrm{BP}$ monitoring (ABPM) device. The drug regimen was not changed from 15 days before the initial study evaluations to the end of the study.

Weight was measured using a Mercy ${ }^{\circledR}$ scale (model LC 200, Brazil, 2010); height was measured with a Welmy ${ }^{\circledR}$ stadiometer (model R110, Brazil, 2009); and body mass index (BMI) was calculated as body weight $(\mathrm{kg}) /$ height $(\mathrm{m})^{2}$, adopting the cutoff limits recommended by the World Health Organization in 1998. ${ }^{10}$

The waist, abdomen, and hip circumferences were measured using a Proximus ${ }^{\circledR}$ retractable and flexible tape measure (Rio de Janeiro, Brazil, 2013).

For measuring the skinfolds, the Cescorf ${ }^{\circledR}$ Mitutoyo caliper (Brazil) was used. The equations proposed by Jackson and Pollock ${ }^{11}$ for men in 1978 and by Jackson et al. ${ }^{12}$ for women in 1980 were used to calculate body density, using the sum of 3 skinfolds. The conversion of body density to body fat percentage was performed using the equation proposed by Siri in 1961. ${ }^{13}$

For all anthropometric and body composition assessments, the methodological recommendations proposed by the International Standards for Anthropometric Assessment were followed. ${ }^{14}$

The 24-h BP recordings were taken by the ABPM device (model Meditech ABPM04; Meditech, Budapest, Hungary). The patients were instructed not to perform any exercise on monitoring days and in the $48 \mathrm{~h}$ that preceded them. The device was programmed to take measurements every $15 \mathrm{~min}$ from 6:00 a.m. to 23:00 p.m. (wakefulness) and every 30 min from 23:00 p.m. to 6:00 p.m. the following morning (sleep). For interpretation, at least 16 measurements during the wakefulness period and 8 measurements during the sleep period were considered valid, following the recommendation of the V Brazilian Guidelines for ABPM. ${ }^{15}$

\section{Exercise Program}

The program lasted 12 weeks with 3 weekly sessions and a minimum frequency of $80 \%$ in the sessions.

The warm-up was conducted on bicycle (model U1X Matrix, Taiwan, 2012), elliptical (model E1X Matrix, Taiwan, 2012), and arm (model Krank Cycle Marix MFC 0002-OS, Taiwan, 2012) ergometers, for 10 min at an intensity of $50 \%$ of the maximum heart rate estimated using the following equation: 208 - (0.7 age). ${ }^{16}$ The relaxation was composed of active and passive stretching exercises. The average time of each session was between 50 and 60 min from the end of the adaptation period.

The RT group followed a sequence of 10 exercises: neutral rowing, squatting, dumbbell supine, knee extension with ankle weights, dumbbell 
development, dumbbell curl, knee flexion with ankle weights, standing plantar flexion, triceps pulley, and trunk flexion. The circuit type of RT was used with intervals of 15-20 s between exercises, with 3 sets of 10 repetitions. Owing to the low physical conditioning and motor coordination of the patients, the loads were stipulated according to their perceived exertion, using the scale of 6-20 proposed by Borg in 1982. ${ }^{17}$ The values used were from 11 to 13 , representing a moderate effort. Then, the load was increased, always aiming at keeping constant values of perceived exertion.

For the AT group, the duration of the main part of the sessions was $40 \mathrm{~min}$. The training was performed on stationary bicycles, elliptical ergometer, and upper-body cycle ergometer, and the patients took turns using the devices. Owing to the use of adrenergic beta-blockers for BP control and the low physical fitness, motor coordination, and mobility of the participants, Borg's scale of subjective perceived exertion ${ }^{17}$ was also used to control the training intensity in this group, with values of the scale ranging from 11 to 13 .

\section{Statistical Analysis}

The sample size was defined using the coefficient of variation previously described in the literature ${ }^{7,18}$ for systolic BP (SBP) (9.1\%) and diastolic BP (DBP) (12.4\%). Considering a 15\% variation around the mean, a minimum number of 5 individuals in each group was determined to be needed to allow checking statistical differences with a significance level of 0.05 .

For the comparison of the RT and AT groups, Student's t-test was used, considering that data presented a normal distribution (Kolmogorov-Smirnov test). To analyze the pre- and post-exercise data, the paired $t$-test and Wilcoxon test were used for normally distributed and non-parametric variables, respectively. The chi-square test was used when the expected frequency of each cell was 5. For the other parameters, Fisher's exact test was used. The significance level adopted was 0.05 . The Sigma Stat version 1.0 and Prism version 3.0 programs were used to perform the analyses and to plot the graphs, respectively.

\section{RESULTS}

Table 1 shows the characteristics of the study sample, composed of 11 participants with $\mathrm{RH}$, who were using 3 or more antihypertensive drugs, were predominantly women, and had a mean age of $60 \pm 8$ years. The baseline BP assessment by the ABPM device revealed that, in patients who performed AT, the 24-h mean arterial pressure (MAP) and the SBP and MAP during wakefulness were significantly higher than those in patients who performed RT. No significant differences were observed between the groups for the anthropometric parameters, lipid profile, fasting glucose level, and time of hypertension.

Table 2 presents the comparison of the anthropometric and biochemical parameters evaluated before and at the end of the 12 weeks of RT and AT. The RT group showed a significant improvement in the level of high-density lipoprotein (HDL) cholesterol. In the other parameters, no significant variations were observed.

Tables 3 and 4 present a comparison of the mean values of SBP, DBP, and MAP both over $24 \mathrm{~h}$ and in the wakefulness and sleep subperiods between patients who performed AT and those who performed RT, at the pre- and post-training moments. Chronic RT did not promote any significant change in BP values over $24 \mathrm{~h}$ and in the evaluated subperiods. When evaluating the AT group, the mean values of SBP, DBP, and MAP were significantly lower in the total of $24 \mathrm{~h}$ analyzed and in the wakefulness subperiod, and the decrease of these 3 measurements in the $24 \mathrm{~h}$ reached approximately 14, 7, and $10 \mathrm{mmHg}$, respectively.

Figures 1 and 2 present the comparisons of the hourly means at the control (pre-training) and post-RT moments, and Figures 3 and 4
Table 1. Characteristics of the sample and basal blood pressure parameters

\begin{tabular}{c|c|c|c|c}
\hline \multicolumn{2}{c|}{ Parameters } & $\begin{array}{c}\text { Resistance } \\
\text { training }\end{array}$ & $\begin{array}{c}\text { Aerobic } \\
\text { training }\end{array}$ & $p$ \\
\hline $\mathrm{n}$ & $5(45 \%)$ & $6(55 \%)$ & $0.499^{*}$ \\
\hline Three or more antihypertensive drugs & $5(45 \%)$ & $6(55 \%)$ & $0.499^{*}$ \\
\hline \multicolumn{2}{c|}{ Number of antihypertensive drugs } & $4.6 \pm 1.7$ & $4.2 \pm 1.2$ & $0.765^{* *}$ \\
\hline \multicolumn{2}{c}{ Men/women } & $1 / 4$ & $2 / 4$ & --- \\
\hline \multicolumn{2}{c|}{ Age (years) } & $58 \pm 11$ & $61 \pm 6$ & $0.345^{* *}$ \\
\hline \multicolumn{2}{c}{ Time of SAH (years) } & $22 \pm 7$ & $19 \pm 8$ & $0.654^{* *}$ \\
\hline \multirow{2}{*}{$\begin{array}{c}\text { Mean values in } \\
24 \text { h (mmHg) }\end{array}$} & SBP & $121 \pm 5$ & $129 \pm 7$ & $0.075^{* *}$ \\
\cline { 2 - 5 } & DBP & $69 \pm 7$ & $74 \pm 4$ & $0.192^{* *}$ \\
\cline { 2 - 5 } & MAP & $86 \pm 5$ & $92 \pm 2$ & $0.034^{* *}$ \\
\hline \multirow{2}{*}{$\begin{array}{c}\text { Mean values in } \\
\text { the wakefulness } \\
\text { period (mmHg) }\end{array}$} & SBP & $122 \pm 6$ & $131 \pm 5$ & $0.024^{* *}$ \\
\cline { 2 - 5 } & DBP & $70 \pm 7$ & $76 \pm 6$ & $0.172^{* *}$ \\
\cline { 2 - 5 } & MAP & $87 \pm 6$ & $94 \pm 3$ & $0.034^{* *}$ \\
\hline \multirow{2}{*}{$\begin{array}{c}\text { Mean values in the } \\
\text { sleep period (mmHg) }\end{array}$} & SBP & $118 \pm 9$ & $119 \pm 18$ & $0.876^{* *}$ \\
\cline { 2 - 5 } & DBP & $62 \pm 12$ & $65 \pm 6$ & $0.635^{* *}$ \\
\cline { 2 - 5 } & MAP & $82 \pm 10$ & $83 \pm 9$ & $0.860^{* *}$ \\
\hline
\end{tabular}

n, sample size; SAH, systemic arterial hypertension; SBP, systolic blood pressure; DBP, diastolic blood pressure MAP, mean arterial pressure. * Chi-square test with data presented as number of participants and percentage. ** Student's $t$-test with data presented as mean \pm standard deviation.

Table 2. Anthropometric and biochemical parameters evaluated before and after the 12 weeks of resistance and aerobic training.

\begin{tabular}{c|c|c|c|c|c|c}
\hline & \multicolumn{3}{|c|}{ Resistance training } & \multicolumn{3}{c}{ Aerobic training } \\
\hline & Pre & Post & $\mathbf{p}^{\ddagger}$ & Pre & Post & $\mathbf{p}^{\ddagger}$ \\
\hline Waist circumference $(\mathrm{cm})$ & $91 \pm 8$ & $91 \pm 4$ & 0.518 & $98 \pm 8$ & $96 \pm 10$ & 0.724 \\
\hline Body fat (\%) & $35 \pm 6$ & $35 \pm 7$ & 0.743 & $31 \pm 7$ & $31 \pm 8$ & 0.991 \\
\hline BMI & $31 \pm 4$ & $31 \pm 6$ & 0.390 & $32 \pm 5$ & $31 \pm 5$ & 0.266 \\
\hline $\begin{array}{c}\text { Fasting glucose } \\
\text { level (mg/dL) }\end{array}$ & $101 \pm 26$ & $88 \pm 14$ & 0.326 & $87 \pm 6$ & $88 \pm 9$ & 0.838 \\
\hline Total cholesterol (mg/dL) & $179 \pm 30$ & $170 \pm 17$ & 0.060 & $180 \pm 16$ & $164 \pm 26$ & 0.155 \\
\hline HDL (mg/dL) & $45 \pm 8$ & $55 \pm 11$ & 0.033 & $41 \pm 11$ & $48 \pm 6$ & 0.256 \\
\hline LDL (mg/dL) & $107 \pm 30$ & $89 \pm 14$ & 0.087 & $103 \pm 23$ & $94 \pm 26$ & 0.323 \\
\hline
\end{tabular}

\begin{tabular}{l|l|l|l|l|l|l} 
Triglycerides $(\mathrm{mg} / \mathrm{dL})$ & $138 \pm 31$ & $135 \pm 43$ & 0.726 & $157 \pm 46$ & $145 \pm 41$ & 0.412 \\
\hline
\end{tabular}

BMI, body mass index; HDL, high-density lipoprotein; LDL, low-density lipoprotein. ${ }^{*}$ Paired $t$-test with data presented as mean \pm standard deviation. Analysis of the lipid profile was performed in 4 participants in the resistance training group.

Table 3. Blood pressure parameters evaluated in patients who performed resistance training $(n=5)$.

\begin{tabular}{c|c|c|c|c}
\hline \multicolumn{2}{c|}{ Parameter } & Pre-training & Post-training & $\mathbf{p}^{\ddagger}$ \\
\hline \multirow{3}{*}{$\begin{array}{c}\text { Mean values in } \\
24 \mathrm{~h}(\mathrm{mmHg})\end{array}$} & SBP & $121 \pm 5$ & $121 \pm 12$ & 0.923 \\
\cline { 2 - 5 } & DBP & $69 \pm 7$ & $69 \pm 7$ & 0.876 \\
\cline { 2 - 5 } & MAP & $86 \pm 5$ & $86 \pm 7$ & 0.672 \\
\hline \multirow{2}{*}{$\begin{array}{c}\text { Mean values in } \\
\text { the wakefulness } \\
\text { period (mmHg) }\end{array}$} & SBP & $122 \pm 6$ & $121 \pm 13$ & 0.342 \\
\cline { 2 - 5 } & DBP & $70 \pm 7$ & $71 \pm 9$ & 0.443 \\
\cline { 2 - 5 } & MAP & $87 \pm 6$ & $88 \pm 9$ & 0.897 \\
\hline \multirow{2}{*}{$\begin{array}{c}\text { Mean values in the } \\
\text { sleep period (mmHg) }\end{array}$} & SBP & $118 \pm 9$ & $120 \pm 11$ & 0.312 \\
\cline { 2 - 5 } & DBP & $62 \pm 12$ & $65 \pm 4$ & 0.267 \\
\cline { 2 - 5 } & MAP & $82 \pm 10$ & $82 \pm 5$ & 0.856 \\
\hline
\end{tabular}

SBP, systolic blood pressure; DBP, diastolic blood pressure; MAP, mean arterial pressure. ${ }^{*}$ Paired $t$-test with data presented as mean \pm standard deviation.

Table 4. Blood pressure parameters evaluated in patients who performed aerobic training $(n=6)$.

\begin{tabular}{c|c|c|c|c}
\hline \multicolumn{2}{c|}{ Parameter } & Pre-training & Post-training & $\mathbf{p}^{\ddagger}$ \\
\hline \multirow{4}{*}{$\begin{array}{c}\text { Mean values in } \\
24 \mathrm{~h} \mathrm{(mmHg)}\end{array}$} & SBP & $129 \pm 7$ & $115 \pm 12$ & 0.045 \\
\cline { 2 - 5 } & DBP & $74 \pm 4$ & $67 \pm 8$ & 0.037 \\
\cline { 2 - 5 } & MAP & $92 \pm 2$ & $82 \pm 8$ & 0.042 \\
\hline \multirow{2}{*}{$\begin{array}{c}\text { Mean values in } \\
\text { the wakefulness } \\
\text { period (mmHg) }\end{array}$} & SBP & $131 \pm 5$ & $117 \pm 14$ & 0.024 \\
\cline { 2 - 5 } & DBP & $76 \pm 6$ & $68 \pm 11$ & 0.042 \\
\cline { 2 - 5 } & MAP & $94 \pm 3$ & $84 \pm 11$ & 0.033 \\
\hline \multirow{2}{*}{$\begin{array}{c}\text { Mean values in the } \\
\text { sleep period (mmHg) }\end{array}$} & SBP & $119 \pm 18$ & $112 \pm 13$ & 0.456 \\
\cline { 2 - 5 } & DBP & $65 \pm 6$ & $63 \pm 4$ & 0.653 \\
\cline { 2 - 5 } & MAP & $83 \pm 9$ & $79 \pm 6$ & 0.514 \\
\hline
\end{tabular}

SBP, systolic blood pressure; DBP, diastolic blood pressure; MAP, mean arterial pressure. ₹ Paired $t$-test with data presented as mean \pm standard deviation. 


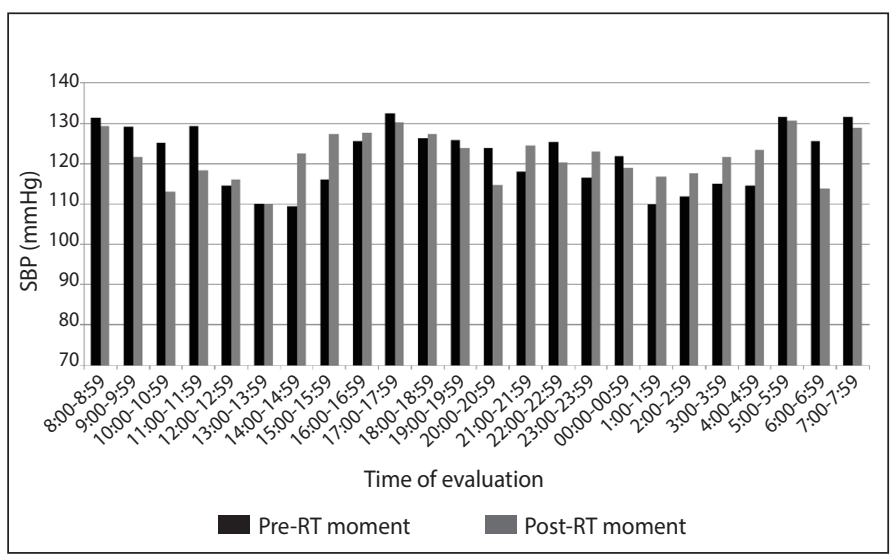

Figure 1. Hourly mean of systolic blood pressure (SBP) at pre-resistance training (pre-RT or control) and post-RT.

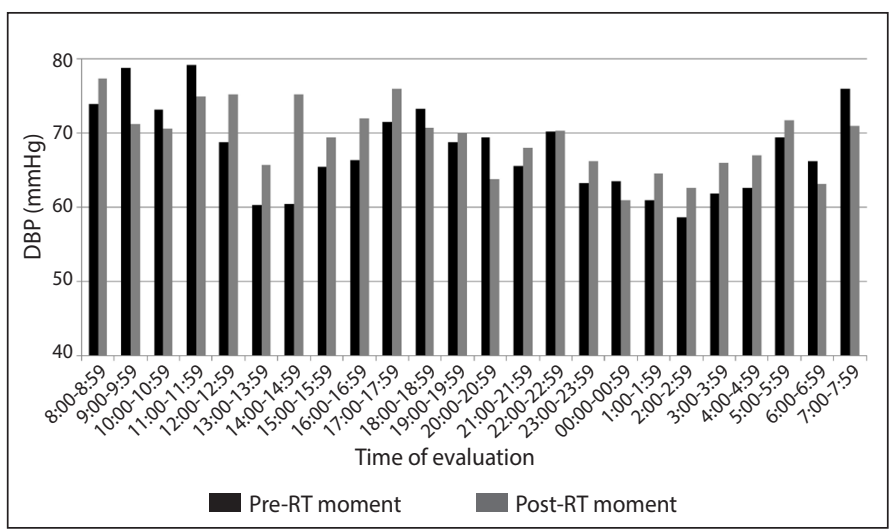

Figure 2. Hourly mean of diastolic blood pressure (DBP) at pre-resistance training (pre-RT or control) and post-RT.

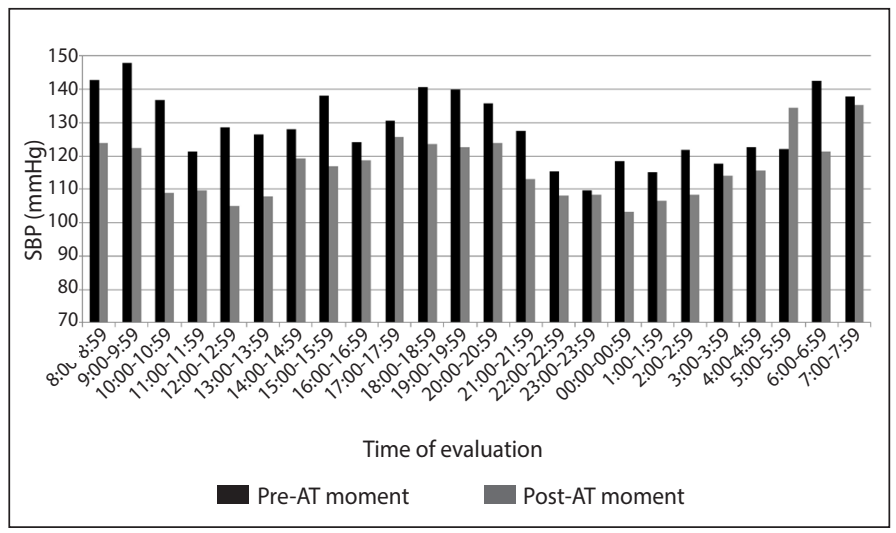

Figure 3. Hourly mean of systolic blood pressure (SBP) at pre-aerobic training (pre-AT or control) and post-AT.

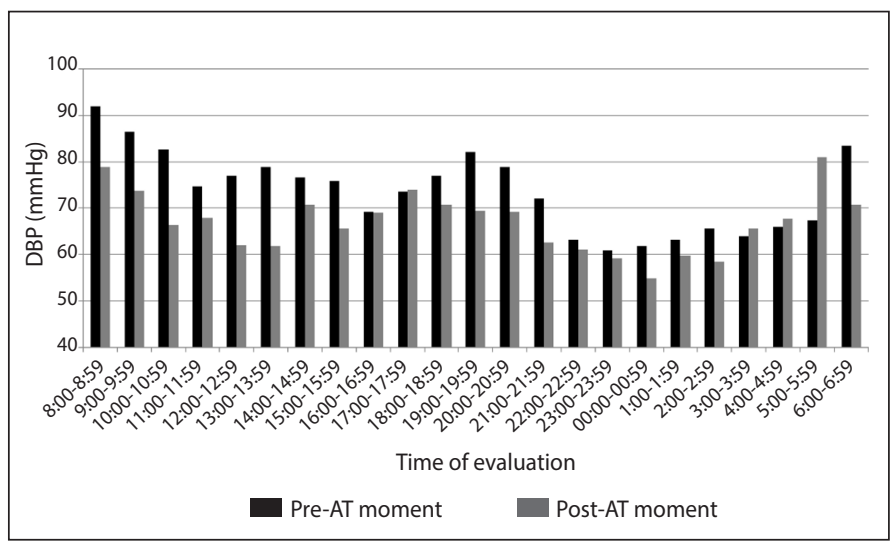

Figure 4. Hourly mean of diastolic blood pressure (DBP) at pre-aerobic training (pre-AT or control) and post-AT. show the comparisons of the hourly means at the control and post-AT moments. It was observed that both SBP and DBP remained lower during almost all moments of the 24-h BP recording that followed the 12 weeks of AT, but more significantly during the wakefulness period. In the 24-h records, after 12 weeks of RT, no significant decrease in BP was observed.

\section{DISCUSSION}

The dose-response relationship between exercise and decrease in $\mathrm{BP}$ is still not fully established, as is the effect of different training modalities on patients with $\mathrm{RH}^{19}$ however, the literature has consistently documented the benefit of exercise in controlling non- $\mathrm{RH}$, especially the benefits of aerobic exercise. $2,9,20$

An article from the American College of Sports Medicine published in 2004 revealed a BP decrease ranging from 5 to $7 \mathrm{mmHg}$ with chronic AT and a reduction of approximately $3 \mathrm{mmHg}$ for SBP and DBP with $R T .{ }^{2}$ Both AT and RT have been associated with reductions in SBP and DBP, although the largest changes were observed in response to $\mathrm{AT}^{20,21}$ Therefore, the data obtained in the present study reinforce the findings of other studies, ${ }^{2,22,23}$ which state that performing aerobic exercises of mild-to-moderate intensity over a short period (12 weeks) is enough to produce positive responses in BP levels and should therefore be recommended as an additional intervention in the treatment of hypertension.

Some studies ${ }^{24,20}$ have already shown the positive effects of RT on $\mathrm{SAH}$. Nevertheless, few clinicians recommend this kind of exercise for patients with cardiovascular disease, owing to concerns about hemodynamic responses. ${ }^{24} \mathrm{~A}$ study by Kim et al..$^{25}$ carried out in 20 hypertensive men between age 68 and 72 years, also showed a significant improvement of SBP and DBP with RT; however, the long period of the intervention (52 weeks) is worth highlighting. In contrast to the evidence cited, in the present study, no significant changes were found in the BP values of patients who performed RT, a finding similar to obtained by Banz et al. ${ }^{26}$ who also did not find significant changes in BP after 10 weeks of resistance exercise.

Resistance exercises can be divided into 2 larger groups: dynamic exercises and static or isometric exercises. Dynamic exercises involve a phase of concentric and eccentric muscle contractions, with varying lengths and tensions of the muscles. Static exercises hold a contraction against a stable load, and there are no changes in the length of the muscles involved. When evaluating the RT protocol, many other variables may explain the results of the studies, such as the number of sets, number of repetitions, recovery times, types of exercises, and exercise intensity. ${ }^{4,20}$

A meta-analysis of 28 clinical studies ${ }^{4}$ evaluated the potential influence of the different characteristics of RT on the BP response. Only 5 studies were performed in hypertensive individuals, and most of them (25 studies) evaluated the effects of dynamic exercises. The duration of the interventions; average frequency per week; intensity; and number of exercises, sets, and repetitions in the evaluated studies were similar to those adopted in our study. There were 3 studies that adopted the circuit type of RT. ${ }^{4}$

Circuit training has a more aerobic characteristic of energy generation, providing greater efficiency in reducing SBP and DBP in hypertensive patients. ${ }^{2}$ Although circuit training has some physiological characteristics distinct from other types of RT, it is considered a strength-training method used to improve the maximum cardiopulmonary capacity, control body weight, expend calories, increase strength, and improve localized muscular endurance, which are important parameters for the studied population. 24,27

In patients with $\mathrm{RH}$, studies that aim to evaluate BP behavior after AT and RT are not common.7,9 To our knowledge, there are only 2 studies with this patient profile, both controlled and randomized. One of them 
evaluated 8-12 weeks of aerobic exercise in patients with $\mathrm{RH}$ and found decreases ranging from $6 \pm 12 \mathrm{mmHg}$ in SBP and $3 \pm 7 \mathrm{mmHg}$ in DBP in the wakefulness subperiod and over $24 \mathrm{~h}$, similar to the results of the present study?

The other study evaluated the effect of 12 weeks of water exercises and observed significant reductions in SBP and DBP over $24 \mathrm{~h}$, in the wakefulness subperiod, and in the sleep subperiod. It has been suggested that the most pronounced BP reductions obtained in this study, from $36.5 \mathrm{mmHg}$ for SBP and $11.9 \mathrm{mmHg}$ for DBP, are due to an additional effect promoted by heated water. ${ }^{9}$

With respect to lipid control and physical exercise, although there is strong scientific evidence showing a favorable relationship, ${ }^{27,28}$ the best type, intensity, and frequency of exercises in this context as well as the most affected lipids remain unclear. ${ }^{27}$ Kesaniemi et al. ${ }^{29}$ reviewed 51 studies and concluded that the increase in HDL was the most consistent improvement related to physical exercise and that the effects on low-density lipoprotein (LDL) and triglycerides are still inconsistently reported.

A study similar to ours, which evaluated 12 weeks of AT, RT, and combined moderate-intensity training, also revealed that the HDL level was significantly higher in the RT group than in the AT group. No significant improvement in other lipid and glucose levels was observed. ${ }^{30} \mathrm{~A}$ review in 2014 also suggested that a moderate-intensity exercise program is effective for increasing $\mathrm{HDL}$; however, for LDL and triglyceride reduction, the intensity of aerobic exercise and the frequency of resistance exercises should be higher, which is often not possible owing to other risk factors and the limited exercise capacity of hypertensive patients. ${ }^{27}$

In the present study, patients who performed AT and those who performed RT did not present changes in BMl, fat percentage, and waist circumference. The lack of dietary control over the 12 weeks of the intervention may have been an influential factor, as cases of increased food intake during the intervention weeks have been found as compensatory behavior. ${ }^{30}$

\section{CONCLUSIONS}

The findings of the present study seem to indicate the importance of low- to moderate-intensity aerobic exercise in persons with $\mathrm{RH}$, even for a short period of adherence of 12 weeks. On the one hand, the proposed methodology of RT or the time of execution did not allow obtaining the same results. On the other hand, this type of training resulted in a significant increase in HDL.

\section{ACKNOWLEDGMENTS}

Financial support from the Minas Gerais Research Support Foundation (Fundação de Amparo à Pesquisa de Minas Gerais) is acknowledged.

All authors declare no potential conflict of interest related to this article

AUTHORS' CONTRIBUTIONS: Each author made significant individual contributions to this manuscript. CJC (0000-0001-8574-6669)*: data collection, data analysis and writing of the article; JCBM (0000-0003-0727-3450)*: data analysis and revision of the article; CGL (0000-0002-6924-5335)*: data collection, data analysis and revision of the article; PRC (0000-00033011-8352)*: data interpretation and writing of the article; HHTR (0000-0001-8755-0651)*: data collection and revision of the article; PRSA (0000-0002-4327-9190)*: data analysis and revision of the article; LML (0000-0001-5349-1577)*: statistical analysis of data, writing and revision of the article. *ORCID (Open Researcher and Contributor ID).

\section{REFERENCES}

1. Sociedade Brasileira de Cardiologia; Sociedade Brasileira de Nefrologia; Sociedade Brasileira de Hipertensão. VI Diretrizes Brasileiras de Hipertensão. Arq Bras Cardiol. 2010:95(1 supl.1):1-51.

2. Pescatello LS, Franklin BA, Fagard R, Farquhar WB, Kelley GA, Ray CA, et al. Exercise and Hypertension. American College of Sports Medicine Position Stand. Med Sci Sports Exerc. 2004;36(3):533-53.

3. Brito $A F$, Oliveira $C V$, Brasileiro-Santos MS, Santos AC. Resistance exercise with different volumes: blood pressure response and forearm blood flow in the hypertensive elderly. Clin Interv Aging. 2014;9:2151-8.

4. Cornelissen VA, Fagard RH, Coeckelberghs E, Vanhees L. Impact of resistance training on blood pressure and other cardiovascular risk factors. Hypertension. 2011;58(5):950-8.

5. Mota MR, Oliveira RJ, Terra DF, Pardoso E, Dutra MT, Almeida JÁ, et al. Acute and chronic effects of resistance exercise on blood pressure in elderly women and the possible influence of ACE I/D polymorphism. Int J Gen Med. 2013;6:581-87.

6. Fagard RH. Resistant hypertension. Heart. 2012;98(3):254-61.

7. Dimeo F, Pagonas N, Seibert F, Arndt R, ZidekW, Westhoff TH. Exercise reduces blood pressure in resistant hypertension. Hypertension. 2012;60(3):653-8.

8. Ribeiro F, Costa R, Mesquita-Barros J. Exercise training in the management of patients with resistant hypertension. World J Cardiol. 2015;7(2):47-51.

9. Guimarães GV, Cruz LGB, Fernandes-Siva MM, Dores EL, Bocchi EA. Heated water-based exercise training reduces 24-hour ambulatory blood pressure levels in resistant hypertensive patients: A randomized controlled trial (Hex trial). Int J Cardiol. 2014;172(2):434-41.

10. World Health Organization. Obesity: preventing and managing the global epidemic. Geneva. 2000.

11. Jackson AS, Pollock ML. Generalized equations for predicting body density of men. Br J Nutr. 1978:40(3):497-504.

12. Jackson AS, Pollock ML, War A. Generalized equations for predicting body density of women. Med Sci Sports Exerc. 1980;12(3):175-82.

13. Siri WE. Body composition from fluid spaces and density. Analysis of methods. In: Brozek J, Hensche A. Techniques for Measuring Body Composition. Washington, DC: National Academy of Sciences; 1961. p. 223-44.

14. Marfell-Jones M, Olds T, Stewart A, Carter L. International standards for anthropometric assessment. Potchefstroom: International Society for the Advancement of Kinanthropometry. 2006.

15. Sociedade Brasileira de Cardiologia. V Diretrizes de Monitorização Ambulatorial da Pressão Arterial (MAPA) e III Diretrizes de Monitorização Residencial de Pressão Arterial (MRPA). Arq Bras Cardiol. 2011 ;97 (3supl.3):1-24.
16. Tanaka H, Monahan KD, Seals DR. Age - Predicted Maximal Heart Revisited. J Am Coll Cardiol. 2001;37(1):153-6

17. Borg G. Psychophysical bases of perceived exertion. Med Sci Sports Exerc. 1982;14(5):377-81

18. Hulley SB, Cummings SR. Estimating sample size and power. In: Designing Clinical Research. Baltimore, Md: Williams and Wilkins; 1988. p.148, Appendlix 13A, 215.

19. Brooks JHM, Ferro A. The physician's role in prescribing physical activity for the prevention and treatment of essential hypertension. JRSM Cardiovasc Dis. 2012;1 (4):12.

20. Cornelissen VA, Smart NA. Exercise Training for Blood Pressure: A Systematic Review and Meta-analysis. J Am Heart Assoc. 2013;2(1):e004473.

21. Souza N, Mendes R, Abrantes C, Sampaio J, Oliveira J. A randomized 9-month satudy of blood pressure and body fat responses to aerobic training versus combined aerobic and resistance training in older men. Exp Gerontol. 2013;48(8):727-33.

22. Pattyn N, Cornelissen VA, Eshghi SRT, Vanhees L. The Effect of Exercise on the Cardiovascular Risk Factors Constituing the Metabolic Syndrome. Sports Med. 2013;43(2):121-33.

23. Cardoso Jr CG, Gomides RS, Queiroz ACC, Pinto LG, Lobo FS, Tinucci T, et al. Acute and Chronic Effects of Aerobic and Resistance Exercise on Ambulatory Blood Pressure. Clinics. 2010;65(3):317-25.

24. Stensvold D, Tjonna AE, Skaug EA, Aspenes S, Stolen T, Wisloff U, et al. Strength training versus aerobic training to modify factors of metabolic syndrome. J Appl Physiol. 2010;108(4):804-10.

25. Kim HS, Kim DG. Effect of long-term resistance exercise on body composition, blood lipid factors, and vascular compliance in the hypertensive elderly men. J Exerc Rehabil. 2013;9(2):271-7.

26. Banz WJ, Maher MA, Thompson WG, Bassett DR, Moore W, Ashraf M, et al. Effects of resistance versus aerobic training on coronary artery disease risk factors. Exp Biol Med. 2003;228(4):434-40.

27. Mann S, Beedie C, Jimenez A. Differential effects of aerobic exercise, resistance training and combined exercise modalities on cholesterol and lipid profile: review, synthesis and recommendations. Sports Med. 2014;44(2):211-21.

28. Sociedade Brasileira de Cardiologia. V Diretriz Brasileira de Dislipidemias e Prevenção de Aterosclerose. Arq Bras Cardiol. 2013;101(4 Supl 1):1-20

29. Kesaniemi YK, Danforth EJ, Jensen MD, Kopelman PG, Lefebvre P, Reeder BA. Dose-response issues concerning physical activity and health: an evidence-based symposium. Med Sci Sports Exerc. 2001;33(6 Suppl):S351-8.

30. Ho SS, Dhaliwal SS, Hills AP, Pal S. The effect of 12 weeks of aerobic, resistance or combination exercise training on cardiovascular risk factors in the overweight and obese in a randomized trial. BMC Public Health. 2012;12:704. 